\title{
Jurisdiction Regarding The Objective Rights Of Buyer Asset-Backed Securities In Secondary Housing Financing
}

\section{Junitin Sinar Humombang. N}

Sumatera University Faculty Of Law. E-mail: junitinsinar@gmail.com

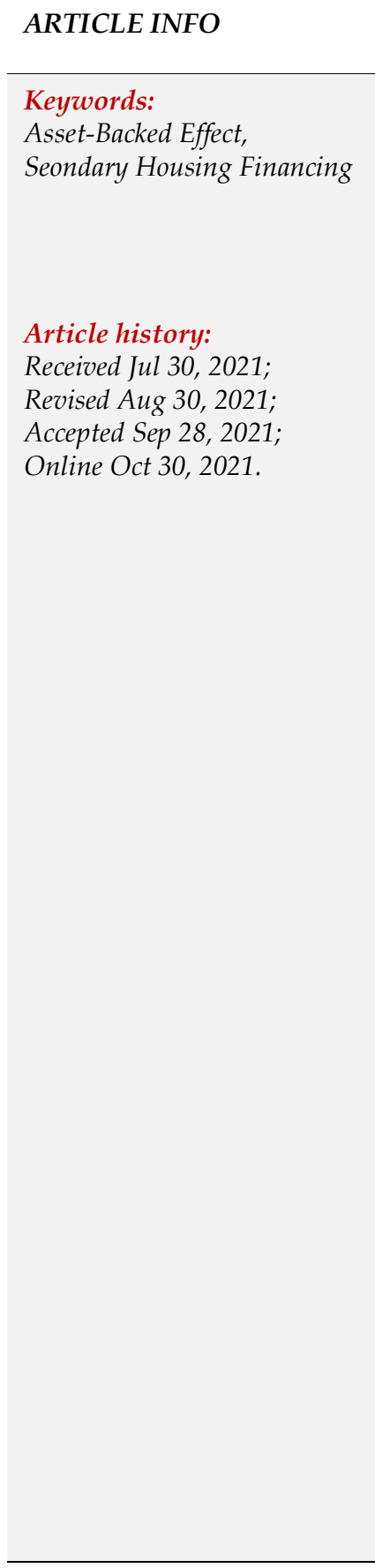

\begin{abstract}
Secondary housing financing is a facility that makes it easier for banks to liquidate their less liquid financial assets in the form of receivables arising from the distribution of Home Ownership Loans (KPR). This needs to be done to avoid mismatch funding. The title of this research is "Juridic Review On The Objective Rights Of The Buyer Of Asset-Backed Securities In Secondary Housing Financing". The research was conducted to find out what are the material rights of asset-backed securities holders in housing secondary financing, how is the transition mechanism, what is the legal protection for asset-backed securities holders and whether national laws need to be adjusted to the concept of secondary housing finance. As for this writing, it can be concluded that the material rights attached to asset-backed securities in housing secondary financing owned by the buyer/holder of asset-backed securities include the right to receive payments, the right to transfer ownership of the asset-backed securities, the right to charge or make asset-backed securities as collateral for the settlement of debts from assetbacked securities holders, the right to obtain settlement of receivables due to mortgage rights on houses and land used as collateral for mortgages (KPR), the right to obtain disclosure of material facts, the right to obtain interest (for asset-backed securities that are debt), the right to Get Settlement of Receivables from the Issuer's Assets. Apart from that, it can also be concluded that the mechanism for the transfer of rights to the issuance of asset-backed securities in secondary housing financing generally consists of 4 phases, namely, among others, the emergence of receivables (receivables) through the distribution of housing loans, sales of receivables by original creditors to third parties. issuer, transfer of material rights in the form of receivables to investors with the issuance of asset-backed securities, transfer of asset-backed securities between one investor to another. Regarding legal protection for buyers/holders of asset-backed securities, it can be concluded that legal protection for buyers/holders of asset-backed securities in secondary mortgage financing is broadly divided into two, namely preventive legal protection and repressive legal protection. Preventive legal protection for holders of asset-backed securities in secondary housing financing lies in implementing the disclosure principle in capital market law, especially in secondary housing financing. Meanwhile, repressive legal protection for asset-backed securities holders consists of 2, namely, legal protection against unlawful acts and legal protection against default acts, both of which must go through a judicial process and cannot be carried out individually but can only be implemented by investment managers in If the asset-backed securities are in the form of securities (equity security)/unit of participation, while if the securities are debt security, the legal action must be carried out through a trustee.
\end{abstract}

This is an open access article under the CC BY-NC license. 


\section{Introduction}

The existence of the Home Ownership Credit (KPR) facility is very helpful for people who want to buy a house considering the price of a house is quite expensive to buy in cash. However, keep in mind that housing loans are long-term loans, whereas in practice, banking funds for providing housing on credit through the issuance of long-term housing loans generally come from savings, current accounts and time deposits, which are short-term funds. If the bank issues KPR continuously with sourced financing.

on short-term funds, the bank will experience a gap between the source and use of funds (mismatch funding).

To overcome these problems, it is necessary to mobilize long-term funds to meet the long-term housing financing needs as well. In line with the Government's program to increase development activities in the housing sector as one of the efforts to provide decent and affordable housing by the community, it is necessary to make efforts to provide adequate funds through secondary housing financing4. To carry out the financing activities in question, a secondary housing finance company was established. The secondary source of housing finance, apart from own capital, is also obtained from the issuer of Asset Backed Securities in the form of Debt Securities and Participation Letters

The implementation of secondary housing financing is a transfer of receivables owned by banks in the form of mortgage loans to the general public as investors. The transfer of receivables is also in accordance with the principles of economic democracy as enshrined in the provisions of Article 2 of Law no. 7 of 1992 in conjunction with Law no. 10 of 1998 concerning Banking which among other things states that banks in carrying out their functions are based on economic democracy. The principle of economic democracy describes democratic values that are derived from the implementation of development as a pillar of the national economy, namely procedural democracy where procedural democracy is defined as a study of democracy with regard to procedures for public participation in state life, so that the jargon of democracy as expressed by Abraham Lincoln which reads "from the people, by the people and for the people" can be reflected in the implementation of the national economy.

The process of mobilizing long-term credit funds is carried out by means of asset securitization, namely by issuing a securities (securities/securities) in which the securities have a guarantee in the form of claims or receivables owned by the original creditor. In other words, the issued securities will be paid through bills or receivables owned by the original creditor, namely claims against customers who apply for Home Ownership Credit (KPR). A security that has a security in the form of a financial asset is referred to as an asset-backed security 6 or in the Common Law tradition the securities are referred to as (Asset Backed Security).

The issuance of such securities by a company or financial institution specifically established for that purpose and the purchase of such securities by the investor community through a public offering mechanism must comply with the provisions of the capital market law, 7 including the provisions regarding the principle of transparency regarding facts. material related to conditions relating to asset-backed securities issued in the context of secondary housing financing through a public offering mechanism. The value or quality of a security is highly dependent on the quality level of the party that issues and sells the securities to the public where in the capital market study the company is referred to as the issuer. When the price of the securities issued by the issuer truly represents the quality of the securities, then this situation is referred to as an efficient market mechanism, namely when the price of securities issued by the issuer is truly a reflection of all information. regarding the quality of the available securities. 
In this case it is clear that the interest of the buyer of securities or in this case the investor community to obtain goods at a price that is in accordance with the quality of the securities is one of the main legal objects in legal arrangements in the capital market where this can only be realized when the parties Issuers in this case want to be open to all information relating to the quality of the securities issued by them. The capital market authority which is held by Bappepam 12 in Indonesia must be able to oblige issuers to be open. The implementation of this is what in the study of capital market law is called the disclosure principle.

As described above, basically secondary housing financing is the process of transferring receivables that arise from the issuance of mortgages by the bank as the owner of the receivables which ultimately flows to the buyer of asset-backed securities in secondary housing financing through the sale and purchase of receivables and the issuance of securities or securities. effect. Therefore, in every act of transferring receivables, whether carried out through the sale and purchase of receivables or through the issuance of asset-backed securities, there will also be a process of transferring material rights as well in which the material rights will eventually be transferred to the buyer of asset-backed securities.

As previously stated, a material fact in secondary housing finance is basically a fact or information that can influence potential investors/buyers of asset-backed securities to buy or not to buy asset-backed securities issued in secondary housing finance. The information is basically something that is attached to the issue of what material rights are owned by the buyer of asset-backed securities in secondary financing for housing and what is the condition or condition of these material rights so that the buyer of asset-backed securities is in secondary financing. made a decision to purchase asset-backed securities in secondary housing finance.

By itself, when potential investors who buy asset-backed securities in secondary housing finance can know and understand what material rights they have and what the conditions of these material rights are before switching to them, potential investors who buy asset-backed securities know and also understand how and what material facts need to be known by him. Apart from that, when the material rights of buyers of asset-backed securities can be understood, it can make it easier to find out how legal protection is for buyers of asset-backed securities in secondary financing.

\section{Method}

Method is a process, principles and procedures for solving a problem, while research is a careful, diligent and thorough examination of a phenomenon to increase human knowledge, so research methods can be interpreted as a process of principles and procedures for solving problems. faced in conducting research. According to Sutrisno Hadi, research or research is an attempt to find, develop, and test the truth of knowledge, which efforts are carried out by scientific methods.

The writing of this thesis is done by using normative research methods. The research method is normative in the sense that in discussing the discussion of the thesis the object discussed is regarding and relating to legal norms and using and processing secondary data to answer the formulation of the problem formulated in the writing of this thesis. The data collection technique is done by means of library research, namely research conducted by examining library materials or what is called secondary data. The secondary data used in writing this thesis, among others, comes from books from private collections and from libraries, articles both taken from print and electronic media, government documents including laws and regulations.

\section{Analysis And Results}




\subsection{Jurisdiction Regarding The Objective Rights Of Buyer Of Asset-Backed Securities In Secondary Housing Financing}

a. Material Rights in Asset Backed Securities in Secondary Housing Financing.

It has been mentioned earlier that what is meant by material rights can simply be said as rights attached to objects. CB Macpherson said that property is not about the object itself but about the rights to the object. In relation to the definition of property, CR Noyes states that "the term of property may be defined to be the interest which can be acquired in external objects or things. The things themselves are not in a true sense, property, but they constitute its foundation and material, and the idea of property springs out the connection or control, or interest which, according to law, may be acquired in them or over them". From the opinion expressed by Noyes, it can be understood that what is meant by property is an interest that can be given to an object or objects. The objects themselves are not in the true sense but they determine the foundation or material and ideas of the property that give rise to the relationship or control or interest that the law can give to these objects.

Therefore, if we are discussing about material rights, of course we will talk about someone's interest in the object, only what is meant by interest here is an interest guaranteed by law, therefore what is meant by right here is legal right. This is in accordance with the meaning of the previously mentioned legal rights, namely "an interest of a person, group or association whose existence is guaranteed by "law" and the implementation of these interests can be forced on every other person before the "law" which has a legal relationship. with that person." Hans Kelsen stated that in every right that is attached to a party, there is always an obligation to the other party.

As previously mentioned, in terms of secondary housing financing, the backed securities issued on secondary housing financing can be broadly divided into 2, namely:

1) Material Rights in Asset Backed Securities that are Equity.

Asset-backed securities in secondary equity housing financing are also known as mortgage pass-through securities (MPTs). In Mortgage pass-through Securities (MPTs), the securities issued are units of participation, which reflects undivided ownership in a pool in which there are various types of mortgage loans. money collected in a container (mutual fund/collective investment) with the intention of being invested in a certain investment container (securities portfolio302) .

The definition of Participation Units can be seen in the Capital Market Law which states that the participation unit is a unit of measure that shows the share of each party's interest in the collective investment portfolio. 303 The container used to collect these funds which will then be invested in a securities portfolio is referred to as mutual. fund. Mutual funds themselves according to the law. The Capital Market is a forum used to raise funds from the investor community to be further invested in securities portfolios by investment managers.304 It can also be said that what is meant by a mutual fund is an investment vehicle that collects a number of funds collected from several investors for the purpose of being invested in in securities such as stocks, bonds, money market instruments and other similar assets.

Mutual funds are operated by investment managers, who invest in mutual funds and seek to generate profits for the fund's investors. The mutual fund portfolio is structured and maintained in accordance with the mutual fund object stated in the prospectus.305 From this understanding, it can be seen that the party who invests the funds collected through the mutual fund into a securities portfolio is called an investment manager. Investment manager is a party whose business activities are managing securities portfolios for customers or managing securities portfolios for customers or managing securities portfolios for customers or managing collective investment portfolios for a group of customers except insurance companies, pension 
funds, what is meant by mutual funds in the terminology of the Civil Code can be referred to as a civil partnership. A civil partnership is an agreement between two or more people who promise to include something in the partnership with the intention that the profits derived from the partnership are shared between 307 If in a civil partnership the "something" that is included can be in the form of money, it can also be in the form of other objects 308 or only in the form of energy309, then in mutual funds, the thing that is included in the partnership must be in the form of money with a certain amount.

In the civil partnership, the party who is the administrator is the party who is made the manager based on the collective investment contract agreement, 310 namely the investment manager with which the partners of the partnership bind themselves in an agreement known as a collective investment contract. A collective investment contract is a contract made by an investment manager (as an investment contract manager) with a custodian bank (as a depositor of mutual fund assets). owned by the partners in the civil partnership. The rights attached to asset-backed securities in secondary housing finance include the following:

a) Right To Get Payment

According to the Civil Code that a civil partnership is formed with the intention of sharing the profits generated by the company.311 Because every partner member in a civil partnership, in this case the holder of the participation unit (mortgage pass-through securities (MPTs)) has the right to obtain the same benefits. generated by a civil partnership which in this case is a mutual fund in housing secondary financing (a pool of receivables that is used as the basis for issuing asset-backed securities in housing secondary financing). The profit sharing is divided proportionally according to the amount (nominal value) of the participation unit (mortgage pass-through securities (MPTs).Although in this case, of course, there is no express agreement regarding the distribution of the profits, but it is something logical if a civil partnership (which in this case is a pool of receivables that is used as the basis for issuing asset-backed securities in secondary housing financing), which equipped with a participation unit as a unit of ownership of the civil partnership, the profit sharing is also divided proportionally according to the ownership of the participation unit in the civil partnership, unless expressly determined otherwise by the members of the partnership. This is in accordance with the Civil Code which states that if the company agreement does not specify the share of each participant from the company's profits and losses,

b) Right to Transfer Ownership of Asset Backed Securities.

As previously mentioned, one of the principles of materiality is that it can be moved or transferred. So in this case what happens is the transfer of material rights from one person to another with all the legal consequences that exist. 314 The transfer of rights to property is carried out through a material agreement (zakelijk overeenkomsten). To know this right, it must first be known about the nature of this asset-backed effect. In simple terms, assetbacked securities are securities issued by the issuer by making the receivables owned by the original creditor as collateral to pay the buyer of the asset-backed securities as his right to get payments as mentioned earlier. From this understanding, it can be seen that the actual value of the asset-backed securities lies in the right of the buyer/holder of the assetbacked securities to demand payment of a certain amount of money.

c) Right to Charge or Make Asset Backed Securities as Collateral for Debt Repayment from Asset Backed Securities Holders.

It has been mentioned earlier that the rights contained in asset-backed securities have their value in the right to demand payment of a certain amount of money from someone (ie the original debtor). Then the right to demand payment or objects in the form of asset-backed securities according to the provisions of Article 511 number 4 of the Civil Code are 
classified as immovable objects. In Indonesian civil law, there are 2 guarantee institutions for an object that is classified as a movable object, namely pawn and fiduciary guarantee. Pawn is a right obtained by the creditor on a movable property, which is handed over to him by the creditor, or by his proxies, as collateral for his debt, and which authorizes the creditor to take the repayment of his receivables and the goods by preempting other creditors.

b. Mechanism of Transfer of Property Rights on Asset Backed Securities in Secondary Financing of Housing.

The mechanism for transferring material rights to asset-backed securities in secondary housing finance consists of 4 phases, which are as follows:

1) The emergence of claim rights (receivables) through the distribution of Home Ownership Loans.

2) Sales of receivables by the original creditor to the issuer

3) Transfer of property rights in the form of receivables to investors by issuing asset-backed securities.

4) Transfer of asset-backed securities among investors..

5) The emergence of the right to collect (receivable) through the distribution of mortgage loans.

The distribution of funds by banks to people who need funds is carried out through a credit agreement, where the credit agreement can be addressed to various things that can be productive or consumptive, including credit agreements between the bank and the customer's community of the bank's debtor to buy or own home for the bank's debtor customers. People who want to buy a house will generally use a Home Ownership Credit (KPR) facility that can be provided by a bank. In this case the bank can provide credit to people who want to buy a house with remuneration in the form of interest at a certain level.

The home ownership credit agreement, in the Civil Code, regulates a lease-to-use agreement. A consumable loan is an agreement that stipulates that the first party submits a number of goods that can be used up to the second party on the condition that the second party will return similar goods to the first party in the same amount and condition. charging interest to debtor customers from the KPR channeling bank, this is also regulated in the Civil Code that in the case of a borrowing and use agreement it can be agreed that the debtor will pay a certain amount of interest.

1) Sales of Receivables by the Original Creditor to the Issuer (Issuer)

After the bank, which in this case acts as the original creditor, has distributed housing loans to its debtor customers, then the bank can carry out the asset securitization process on its receivable assets if necessary. In carrying out the asset securitization process, it has been said that the process that must be passed first is the sale of receivables by the bank (original creditor) to the issuer. The sale-purchase agreement of the receivables must be made with a cutoff sale.

2) Transfer of Property Rights in the form of Receivables to Investors by Issuing Asset Backed Securities.

After the receivables owned by the original creditor have been sold to the issuer and have been handed over to the issuer, then in the securitization process the next process is the process of issuing asset-backed securities to be purchased by the investor community. The purchase of securities by investors has indicated that the asset securitization process in secondary housing financing is in the final stage. Investors who want to buy asset-backed securities in secondary housing finance buy them in a primary market in the capital market. The primary market is the market that issues new securities on an exchange. Companies and governments and other groups obtain financing through equity or debt securities. 
In the event that the asset-backed securities in the secondary housing financing issued are equity securities (in this case, mortgage pass-through security, then each securities in the form of participation units issued are attached to the investors' joint ownership rights over receivables). receivables that are used as the basis for the issuance of the underlying asset. In this case, there is a transfer of rights in the form of these receivables from the issuer (issuer) to investors together. In other words, the respective investors have rights to the receivables in accordance with their proportional ownership based on the unit of participation they have.

3) Transfer of Asset Backed Securities between One Investor to Another Investor.

The process of transferring asset-backed securities between one investor to another occurs in a process known as trading. This trading process is the process after the asset securitization process is carried out, namely the activity/process of trading securities between one investor and another, thereby transferring the securities from one investor to another. Trading activities occur in the secondary market (secondary market). The secondary market is a market where investors buy securities or assets from other investors, as opposed to direct issuance by the securities issuing company it self.

It can also be said that what is meant by the secondary market is the stage of buying and selling after the primary market occurs. Here, before the secondary market operates, the securities sold by the issuer/issuer to investors are first listed on the stock exchange. After the listing becomes effective, the securities are then traded on the stock exchange where the securities are listed. So in the secondary market, the buying and selling of securities takes place entirely on the stock exchange by and between investors.

\section{c. Legal Protection for Buyers of Asset Backed Securities in Secondary Financing for Housing.}

According to Philipus M Hadjon Legal protection in Dutch legal literature is known as "rechtbescherming van de burgers."359 This opinion shows that the word legal protection is a translation of the Dutch language, namely "rechtbescheming". This means that the notion of legal protection interpreted as an attempt to provide the rights of the protected party in accordance with the obligations that have been carried out Protection of investors is a state obligation. The country in question is Bapepam in accordance with Law No. 8 of 1995 concerning the Capital Market. Investor protection is an application of justice to all investors. Justice is a legal goal that must be upheld by the state and society. Philipus M. Hadjon stated that basically legal protection includes: 2 things, namely preventive legal protection and repressive legal protection. Preventive legal protection includes actions that lead to efforts to prevent disputes from occurring while repressive protection means protection that is directed more towards efforts to resolve disputes, for example, dispute resolution in court.

1) Preventive Legal Protection.

This preventive legal protection is a form of protection provided by law to prevent unwanted things from happening in the law, namely the violation of the rights of everyone in society. In this case, preventive legal protection is protection provided by law to prevent investors' rights to material rights in asset-backed securities in secondary financing from being violated by irresponsible parties.

Preventive protection provided by law to holders/buyers of asset-backed securities is the provision of the disclosure principle. The principle of openness is a core issue in the capital market and at the same time is the soul of the capital market itself. Disclosure about material facts as the soul of the capital market is based on the existence of the principle of openness that allows for the availability of considerations for investors, so that they can rationally make decisions to buy or sell securities in the capital market. 362 According to the Capital Market 
Law, it is stated that what is meant by with the principle of openness are general guidelines that require issuers, public companies.

2) Repressive Legal Protection.

Repressive protection means protection that is directed more towards efforts to resolve disputes, for example, dispute resolution in court. It has been mentioned earlier that what is meant by rights are. "an interest of a person, group or association whose existence is guaranteed by law, and the implementation of that interest can be imposed on every other person before the "law" who has a legal relationship with that person." From this understanding, it can be understood that the law in this case provides protection to each individual so that each individual can get what is their right. Therefore, legal protection is identical to the protection of the rights possessed by each individual by placing obligations for other parties and can provide a forced effort to parties who neglect their obligations.

\section{d. Adjustment of the National Law on the Concept of Secondary Financing for Housing in} Indonesia.

The laws and regulations regarding the capital market in Indonesia as regulated in Law no. 8 of 1995 concerning the Capital Market is basically similar to or the same as the laws and regulations of the United States Capital Market.378 The laws and regulations of the United States are built using the common law legal system, while the laws and regulations in Indonesia are built using the civil law legal system. . Of course, when the capital market legislation in Indonesia imitates the United States capital market legislation, it will certainly face problems related to the differences in the legal system. One of these problems is the existence of legal institutions that are embraced in the laws and regulations on the capital market in Indonesia which are actually not known in the Civil Law legal system.

Trust is a very popular and distinctive institution in English law (Common Law). Basically in what is called a beneficiary. The person who entrusts the wealth is called a trustor and the person who is trusted is called a trustee.379 In the case that it is made with an agreement or agreement, it is somewhat similar to what in the Civil Code is called an agreement with a promise to a third party (derdenbeding) according to Article 1317 of the Civil Code. 380 Article 1317 The Civil Code states that "An agreement can also be made for the benefit of a third person, if an agreement made for oneself, or a gift to another person, contains such conditions. Anyone who has determined a condition may not withdraw it, if a third party has stated that he will use the condition ".

Whereas in order to guarantee protection for investors in secondary housing finance, it is necessary to make a certain standard in the law that regulates the standard of transparency principle that must be implemented by issuers, originating creditors and other parties who are required to implement the principle of transparency. caution. In order to facilitate the investor community in the capital market in general and in secondary housing financing in particular in order to protect rights, it is necessary to establish an arbitration body under the Financial Services Authority in order to resolve disputes regarding the implementation of the capital market in general. and implementation of secondary housing finance in particular.

\section{Conclusion}

Material rights attached to asset-backed securities in housing secondary financing owned by buyers/holders of asset-backed securities include the right to receive payments, the right to transfer ownership of the asset-backed securities, the right to charge or make asset-backed securities as collateral for debt repayment. from asset-backed securities holders, rights to obtain repayment of receivables due to mortgage rights on houses and land that are used as collateral for mortgages (KPR), rights to obtain disclosure of material facts, rights to earn interest (for 
asset-backed securities that are debt) ), and the right to Get Settlement of Receivables from the Assets of the Issuer. (for asset-backed securities that are debt).

Apart from that, it can also be concluded that the mechanism for the transfer of rights in the issuance of asset-backed securities in secondary housing financing generally consists of 4 phases, namely, among others, the phase of the emergence of receivables (receivables) through the distribution of housing loans, the phase of selling receivables by original creditor to the issuer, transfer of material rights in the form of receivables to investors with the issuance of asset-backed securities, transfer of asset-backed securities between one investor to another investor. The 2 phases of the 4 phases are not subject to capital market law, but are subject to the provisions of civil law regarding credit agreements (borrowing and borrowing money), and regarding the sale and purchase of receivables, while the last 2 phases are subject to capital market law.

Regarding legal protection for buyers/holders of asset-backed securities, it can be concluded that legal protection for buyers/holders of asset-backed securities in secondary mortgage financing is broadly divided into two, namely preventive legal protection and repressive legal protection. Preventive legal protection for holders of asset-backed securities in secondary housing financing lies in implementing the disclosure principle in capital market law, especially in secondary housing financing. While the repressive legal protection for assetbacked securities holders consists of 2, namely, legal protection against unlawful acts and legal protection against default acts.

It can also be concluded that it is necessary to make some adjustments to the national law on the concept of secondary housing finance, especially regarding trust institutions contained in secondary housing finance, because trust institutions are not known in the legal system in Indonesia.

\section{References}

Anoraga, Pandji Anoraga \& Pakarti, Piji, 2001, Introduction to Capital Markets, Rineka Cipta, Semarang.

Asshidiqie, Jimly, 2006, Regarding the Law, Secretariat General and Registrar of the Indonesian Constitutional Court, Jakarta.

Beaver, William H., 1980, The Nature of Mandate Disclosure, Boston, Little, Brown \& Company.

Bruggink, JJH, Reflections on Law, Translation: Arif Sidharta, 1996, Citra Aditya Bakti, Bandung.

CB Macpherson, 1978, Property : Mainstream and Critical Position, Toronto.

CR Noyes, 1936, The Institution of Property, New York.

Curzon, LB, 1967, Equity, London, MacDonald \& Evans Ltd.

Deacon, John, 2004, Global Securitization and CDOs, Chichester; John Wiley \& Sons Ltd.

Easterbrook, Frank \& Fischel, Daniel R, 1996, The Economic Structure of Corporate Law, Cambridge Massachusetts, Harvard University Press.

Hadi, Sutrisno, 2000, Research Methodology, Volume I, Andi Foundation, Yogyakarta. Harahap, M. Yahya, 2005, Civil Procedure Law, Jakarta, Sinar Graphic offsets .

Hasbullah, Frieda Husni, 2005, Civil Material Law, Rights that Give Enjoyment, Ind-Hill-Co, Jakarta. 
Hyderabad , RL \& Mohana Rao, 2002 , Financial Services text, Casest and Strategy, New Delhi, Deep \& Deep Publication Pvt Ltd.

Ibrahim, Johannes \& Sewu, Lindawaty, 2003, Business Law in a Modern Perspective, Refika Aditama, Jakarta.

K. Bertens, 2000, Introduction to Business Ethics, Kanisius, Yogyakarta.

K. Smith and DJ Keane, 1980, Company Law, 3rd edition, London, McGraw Hill Inc.

Kelsen, Hans, 1949, The General Theory of Law and State, Cambridge Massachusetts, Harvard University Press.

Keown, Arthur, 1996, Basic Financial Management, 7th edtition, Prentice Hall International.

Matlock Odgen, James Matlock Odgen, 1922, The Law of Negotiable Instruments, Chicago, Callaghan \& Company, p. 17.

Mertokusumo, Sudikno, 2003, Knowing the Law (An Introduction), Liberty, Yogyakarta.

Mulyadi, Kartini \& Gunawan Widjaja, 2004, Privileges, Pawns, and Mortgages, Kencana Prenada Media Group, Jakarta.

Mulyadi, Kartini \& Gunawan Widjaya, 2003, Materials in General, Kencana Prenada Media, Jakarta.

Mustafa, Bachsan, 2003, Integrated Indonesian Legal System, Citra Aditya Bakti, Bandung.

Nasution , Bismar, 2009, Law of Economic Activities, Medan, Books Terrace \& Library

Nasution, Bismar, 2001, Transparency in the Capital Market, UI Press, Jakarta.

National Bureau of Economic Research, 2007, The Risk of Financial Institutions, Chicago, University of Chicago Press O. Notohamidjojo, 1971, Problem: Justice, Tirta Amerta, Semarang.

P Mohana Rao \& RL Hyderabad, 2002, Financial Services text, Casest and Strategy, New Delhi , Deep \& Deep Publication Pvt Ltd.

Paton, GW, 1964, A Text Book of Jurisprudence, Oxford University Press, Philipus M. Hadjon, 1987, Legal Protection for the Indonesian People, Science Development, Jakarta.

Rahardjo, Satjipto, 2006, Legal Studies, Citra Aditya Bakti, Semarang. Satrio , J, 1996, About the Abolition of Engagement, Book II, Citra Aditya Bakti, Bandung.

Satrio, J, 1999, Associations in General, Alumni, Bandung.

Satrio, J, 2009, Cessie. Bills in the Name, DNC Foundation, Purwokerto. Schouler, James, 1907, Law of Personal Property, Boston, Little Brown and Company.

Siegel, Joe G \& Shim, Jae K., 1996, Dictionary of Accounting Terms, Jakarta, Media Elex Komputindo.

Simon, Harry \& Brock, WE Due, 1989, Advanced Accounting, Taipei, Meyya Publication.

Soeharnoko \& Hartati, Endah, 2008 The Doctrine of Subrogation, Novation and Cessie cet.3, Kencana, Jakarta.

Soekanto, Soerjono, 1986, Introduction to Legal Research, UI Press, Jakarta. Subekti, 1982, Fundamentals of Civil Law, Intermasa, Jakarta.

Subekti, 1995, Various Agreements, Citra Aditya Bakti, Bandung. 
Subekti, 1996, Comparative Civil Law, Pradnya Paramitha, Jakarta. Subekti, 2001, Covenant Law, eighteenth edition, Intermasa, Jakarta. Study. Adrian, 2008, Legal Aspects of Bonds and Sukuk, Sinar Graphic, Jakarta. Suyuthi, Wildan, 2004, Seizure of Judicial Judicial Practice Executions, Tatanusa, Jakarta.

US Comptroller of The Currency Administrator of National Bank, 1997, Asset Securitization Comptroller's Handbook, US Treasury.

Utrecht, E. \& Moh. Saleh Djindang, 1982 Introduction to Indonesian Law, Ichtiar Baru, Jakarta.

Widjaja, Gunawan, 2004, Effects as Objects, Rajawali Press, Jakarta. Widjaja, Gunawan \& E Paramitha Sapardan, 2005, Series on Legal Aspects in Capital Market; Asset Securitization (Implementation of SMF in Indonesia), Raja Grafindo Persada, Jakarta.

Yudha Hernoko, Agus, 2009, Law on Proportionality Principle Agreements in Commercial Contracts, Kencana Prenada Group, Surabaya.

Yulfasni, 2005, Capital Market Law, Jakarta, Iblam Publishing Agency.

Civil Code (KUHPerdata) Commercial Code (KUHD) Law No. 7 of 1992 concerning Banking Law No. 8 of 1995 concerning the Capital Market.

UU no. 10 of 1998 concerning Amendments to Law no. 7 of 1992 concerning Banking.

Law No. 42 of 1999 concerning Fiduciary Guarantees. Law No. 16 of 2001 concerning Foundations.

Law No. 21 of 2011 concerning the Financial Services Authority. 4 of 1996 concerning Mortgage Rights.

UU no. 5 of 1960 concerning Agrarian Principles Law No. 17 of 2012 concerning Cooperatives.

Law No.40 of 2007 concerning Limited Liability Companies PP no. 24 of 1997 concerning Land Registration.

Presidential Decree No. 19 of 2005 concerning Secondary Financing for Housing Director General of Taxes Decree No. Kep-147/PJ/2003 dated May 13, 2003.

concerning Income Tax on Income Received or Obtained by Collective Investment Contracts of Asset Backed Securities and their Investors.

Bank Indonesia Regulation No.7/4/PBI/2005 concerning Prudential Principles in Asset Securitization Activities for Commercial Banks.

Bapepam Regulation No. IX.C.10 concerning Guidelines for the Form and Content of a Prospectus for Public Offering of Asset Backed Securities.

Bapepam Regulation No. IX.C.9 concerning Registration Statement for Public Offering of Asset Backed Securities.

Bapepam Regulation No. IX.K.1 concerning Guidelines for Collective Investment Contracts for Asset Backed Securities.

Bapepam Regulation No. VG5 on Investment Manager Functions Relating to Asset Backed Securities.

Bapepam Regulation No.VI.A.2 concerning Custodian Bank Functions relating to Asset Backed Securities. 